\title{
Estimating herbage standing crop with visual obstruction in tallgrass prairie
}

\author{
LANCE T. VERMEIRE AND ROBERT L. GILLEN
}

Authors are research assistant, Department of Range, Wildlife, and Fisheries Management, Texas Tech University, Lubbock, Tex. 79409-2125, and rangeland scientist, USDA-ARS, Southern Plains Range Research Station, Woodward, Okla. 73801. At the time of research, authors were research assistant and professor, Department of Plant and Soil Sciences, Oklahoma State University, Stillwater, Okla. 74078-0507.

\begin{abstract}
We evaluated the visual obstruction method as a non-destructive means of estimating herbage standing crop in tallgrass prairie. Prediction models were developed for both plot-level and pasture-level estimates by regressing standing crop from clipped plots on visual obstruction measurements (VOM) from 48, 20sample trials. Trials were conducted year-round on burned and non-burned sites in different seral stages and with various levels of productivity and grazing pressure. Separate models were required for burned and non-burned pastures, but both applied across all other variables and were unaffected by community heterogeneity. Coefficients of determination were 0.95 and 0.90 for burned and non-burned pastures, respectively. Use of a more precise measurement scale for visual obstruction did not improve the prediction models. Models for standing crop based on individual quadrats explained less variation than models based on transect averages. The highest correlations with visual obstruction were obtained with $20 \times 50 \mathrm{~cm}$ quadrats placed adjacent to the measurement pole and oriented toward the observer. The visual obstruction method required little training and mean deviations of student readings from those of the trainer were less than $1 \mathrm{~cm}$. Sampling efficiency is improved with the visual obstruction method because it is reasonably accurate and 6 times faster than clipping. Standing crop estimates can be calculated immediately and less field equipment is needed.
\end{abstract}

Key Words: non-destructive sampling, ocular estimation, prescribed burning, Robel pole

Measurements of herbage standing crop are often required for effective rangeland management. Standing crop can be measured directly by clipping herbage from random quadrats and extrapolating dry weight over the area of interest. The level of accuracy produced by direct measurement depends primarily on the sampling design. Although clipping is accurate, it is often dreaded by researchers and altogether avoided by many land managers because of the time and labor required to harvest the vegetation. Drying and weighing of vegetation also delay the calculation of standing crop estimates.

Numerous indirect methods have been tested to expedite the estimation of herbaceous standing crop, but accuracy is sacrificed and the applicability of individual models is typically limited

Manuscript accepted 20 Mar. 2000

\section{Resumen}

Evaluamos el método de obstrucción visual como un medio no destructivo para estimar la cosecha de forraje en pie de praderas de zacates altos. Se desarrollaron modelos de predicción para las estimaciones a nivel de parcela y a nivel de potrero, esto se realizo mediante regresiones entre la cosecha en pie cortada de las parcelas y las mediciones obtenidas con el método de obstrucción visual en 48 ensayos de 20 muestras cada uno. Los ensayos se condujeron a lo largo del año en sitios quemados y no quemados, con diferentes etapas serales y con varios niveles de productividad y presión de apacentamiento. Se requirieron modelos separados para los potreros quemados y no quemados, pero ambos aplicaron a lo largo de otras variables $y$ no fueron afectados por la heterogeneidad de la comunidad. Los coeficientes de determinación fueron de 0.95 y 0.90 para los potreros quemados y no quemados respectivamente. El uso de una escala de medición mas precisa en el método de obstrucción visual no mejora los modelos de predicción. Los modelos para la cosecha en pie basados en cuadrantes individuales explicaron menos la variación que los modelos basados en los promedios de transectos. Las mas altas correlaciones con la obstrucción visual fueron obtenidas con cuadrantes de $20 \times 50 \mathrm{~cm}$ ubicados adyacentemente de el poste de medida y orientados hacia el observador. El método de obstrucción visual requiere poco entrenamiento y la media de desviación entre las lecturas de estudiantes y la del entrenador fue menos de $1 \mathrm{~cm}$. La eficiencia de muestreo es mejorada con el método de obstrucción visual porque es razonablemente certero y 6 veces mas rápido que el corte. Las estimaciones de la cosecha en pie pueden ser calculadas inmediatamente y se requiere menos equipo de campo.

(Michalk and Herbert 1977, Gonzalez et al. 1990, Catchpole and Wheeler 1992, Harmoney et al. 1997). However, Robel et al. (1970) detected a strong relationship between visual obstruction measurements (VOM) and standing crop in homogeneous tallgrass communities. Our overall objective was to assess the effectiveness of VOM as a non-destructive method of estimating herbaceous standing crop. Specific objectives were to: 1) determine the effects of season of year and fire management on VOM, 2) assess the effect of the precision of the measurement scale used for VOM on the resulting estimates of standing crop, 3) evaluate the effects of quadrat size and positioning, and 4) examine the time and training required to use the visual obstruction method. 


\section{Materials and Methods}

\section{Study area}

The study was conducted from 1994 to 1996 on native tallgrass prairie near Stillwater, Okla. $\left(36^{\circ} 04^{\prime} \mathrm{N}, 97^{\circ} 13^{\prime} \mathrm{W}\right)$. The continental climate allows a 204-day frost-free growing season from April to October. Mean annual temperature is $15^{\circ}$ $\mathrm{C}$, with an average daily minimum of $-4.3^{\circ} \mathrm{C}$ in January and an average daily maximum of $34^{\circ} \mathrm{C}$ in August. Mean annual precipitation is $831 \mathrm{~mm}$, with $65 \%$ falling as rain from May to October (Myers 1982). Growing-season (May to August) precipitation from 1994 to 1996 was 70,169 , and $114 \%$ of the long-term (1893 to 1980) mean, respectively.

Range sites used in the study included sandy savannah, loamy prairie, shallow prairie, and eroded prairie. Dominant grasses were big bluestem [Andropogon gerardii Vitman], little bluestem [Schizachyrium scoparium (Michx.) Nash], indiangrass [Sorghastrum nutans (L.) Nash], and tall dropseed [Sporobolus asper (Michx.) Kunth]. Western ragweed [Ambrosia psilostachya DC] and annual broomweed [Amphiachyris dracunculoides (DC) Nutt. ex Rydb.] were the dominant forbs. Grama grasses [Bouteloua spp. Lag.], annual threeawn [Aristida oligantha Michx.], and forbs were more prominent on sites in lower seral stages.

\section{Methods}

We conducted 48 trials over a wide array of standing crops and species composition. Each trial consisted of 20 plots arranged systematically along a pace transect with an approximate distance of $15 \mathrm{~m}$ between plots. All sites were exposed to cattle grazing at various stocking rates under short-duration, intensive-early stocking, or continuous season-long grazing systems. Trials were performed during the growing season following spring prescribed burns $(n=17)$, during the growing season without prescribed burning $(\mathrm{n}=$ $19)$, and during plant dormancy $(n=12)$. Average herbaceous standing crop among trials ranged from 570 to $3,390 \mathrm{~kg} \mathrm{ha}^{-1}$ in burned pastures and 1,680 to $6,630 \mathrm{~kg} \mathrm{ha}^{-1}$ in non-burned pastures. Herbaceous standing crop among individual plots ranged from 220 to $6,280 \mathrm{~kg} \mathrm{ha}^{-1}$ in burned pastures and 220 to $13,370 \mathrm{~kg} \mathrm{ha}^{-1}$ in nonburned pastures.

Our use of the visual obstruction method was based on the methods of Robel et al. (1970) with modifications of the measurement pole and the number of observations taken per plot. The measurement pole was a wooden dowel $(2.5 \times 100 \mathrm{~cm})$ with alternating red and white bands $1 \mathrm{dm}$ wide and black lines at $2.5-\mathrm{cm}$ intervals. A second wooden dowel $(1 \mathrm{~cm} \times 1 \mathrm{~m})$ was attached to the measurement pole by a 4-m string to locate a consistent observation point $4 \mathrm{~m}$ from the measurement pole and $1 \mathrm{~m}$ above the ground level. The measurement pole was placed at the center of the $20-\mathrm{cm}$ side of each $20 \times 50 \mathrm{~cm}$ plot, on the side opposite the observer. A single visual obstruction reading was taken for each plot by recording the height of the lowest visible increment on the pole. The mark was considered visible if any portion of it could be seen. Visual obstruction readings were recorded in both 2.5 and $5.0-\mathrm{cm}$ increments to assess whether measurement increment influenced the precision of prediction models. Vegetation in the plot was then clipped to ground level and ovendried to a constant weight to determine standing crop. Quadrats from the first 15 trials were divided into two, $20 \times 25 \mathrm{~cm}$ subplots to examine the effects of altering plot size and location. One subplot was the half of the plot adjacent to the measurement pole and the other subplot was the half of the plot nearer to the observer.

Sampling time was noted from the time of placing the quadrat or pole to completion of the plot measurements (visual obstruction and clipping). Two levels of training were employed to evaluate the impact of this factor on the visual obstruction method. First, 20 plots representing a range of standing crops were marked on a site. A brief (1 to 2 min.) verbal overview of VOM was given to 3 graduate students. Each student then recorded independent readings from 10 of the marked plots. The method was then described a second time in more detail, 5 visual demonstrations were made, and questions were discussed ( 5 to $10 \mathrm{~min}$.). The students then made independent readings on the remaining 10 marked plots. Deviations of students'

Table 1. Visual obstruction regression coefficients and statistics for burned and non-burned pastures measured by 2.5 and $5.0-\mathrm{cm}$ increments.

\begin{tabular}{|c|c|c|c|c|}
\hline & \multicolumn{2}{|c|}{ Burned pastures } & \multicolumn{2}{|c|}{ Non-burned pastures } \\
\hline & \multicolumn{4}{|c|}{ Visual obstructive increment $(\mathrm{cm})$} \\
\hline & 2.5 & 5.0 & 2.5 & 5.0 \\
\hline Slope & $129^{\mathrm{a}} \quad(8)^{\mathrm{b}}$ & $130 \quad(8)$ & $174(11)$ & $175 \quad(11)$ \\
\hline Intercept & $-21^{c}(116)$ & $-202(124)$ & $398(200)$ & $160(212)$ \\
\hline Coefficient of determination $\left(\mathrm{r}^{2}\right)$ & 0.95 & 0.95 & 0.90 & 0.90 \\
\hline Maximum estimate error ${ }^{d}$ & ------ & ------- $(1$ & $\left.a^{-1}\right)$-------- & ------------- \\
\hline Smallest & 110 & 108 & 147 & 147 \\
\hline Largest & 272 & 273 & 438 & 427 \\
\hline Mean & 155 & 154 & 209 & 207 \\
\hline
\end{tabular}

${ }^{a}$ All slopes are different from $0(\mathrm{P}<0.05)$

${ }^{\mathrm{b}}$ Standard error of estimate

${ }^{\mathrm{c}}$ All intercepts are similar and not different from $0(\mathrm{P}>0.05)$

${ }^{\mathrm{d}}$ Range and mean of maximum estimate errors were calculated from $95 \%$ confidence intervals. readings from those of the trainer were

Relationships between standing crop and visual obstruction were determined by regression analysis using either trial means or individual plots as observations (SAS 1985). Indicator regression was used to identify differences in models by season, burning treatment, and measurement increments (Neter et al. 1990). For trial data, residuals were regressed on coefficients of variation of standing crop to assess the effects of community heterogeneity on the prediction capabilities of VOM models. We evaluated the relationships between visual obstruction readings and standing crop from subplots and whole plots by correlation analysis (SAS 1985). All results are based on $2.5-\mathrm{cm}$ visual obstruction increments except when 2.5- and 5.0-cm increments are being directly compared.

We calculated $95 \%$ prediction intervals for standing crop for the regression models based on trial means. Using the variances of standing crop estimated from clipping for each trial, we used Stein's formula (Steel and Torrie 1980) to calculate the number of clip plots required to achieve the same precision as the regression model. We compared the field time required for each method by multiplying the minutes per clip plot times the estimated number of clip plots and the minutes per visual obstruction measurement times 20 (the regression model was based on trials of 20 observations).

\section{Results and Discussion}

Prediction models did not differ between dormant and growing season trials $(\mathrm{P}=0.85)$, but were affected by fire management $(\mathrm{P}<0.01)$. Burned pastures had less biomass per $\mathrm{cm}$ of visual obstruccalculated for each level of training. 


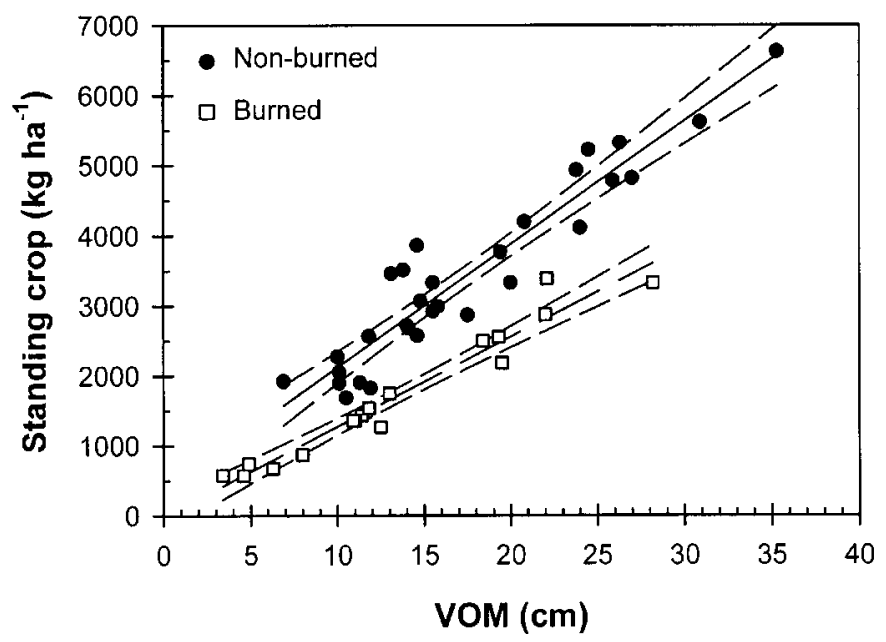

Fig. 1. Relationships between standing crop and visual obstruction measurements (VOM) with 95\% confidence intervals for 17 burned and 31 non-burned pasture trials. tion than non-burned pastures (Fig. 1). At least $90 \%$ of the variation in standing crop was explained by visual obstruction and estimate errors were low for both burned and non-burned pastures (Table 1).

Our models appear robust for heterogeneous tallgrass communities with a wide range of standing crop and species composition. Coefficients of determination were similar to the 0.95 value Robel et al. (1970) achieved using similar measurement procedures on homogeneous sites. Regression coefficients are not comparable between the 2 studies because Robel et al. (1970) did not collect the lower $5 \mathrm{~cm}$ of standing crop.

Although standing crop from growingwith a single model, differences could occur in some areas. The ratio of standing crop to visual obstruction may be reduced as plants become weathered (Ratliff and Heady 1962, Pieper et al. 1974), or increase if heavy snow or wind compress the vegetation. Significant lodging was not encountered in this study.

Burned pastures supported less biomass per centimeter of visual obstruction because standing dead biomass from previous years' growth had largely been consumed by fire. Heavily grazed pastures might produce the same effect since limited amounts of standing dead biomass are retained between years. On the other hand, regression models from pastures rested for long periods might have greater slopes than models from our non-burned pastures because larger amounts of standing dead biomass would have been accumulated.

Residuals were not related to trial standing crop C.V. for burned $(\mathrm{P}=0.22)$ or non-burned $(\mathrm{P}=0.18)$ pastures, indicating and dormant-season trials was explained prediction capabilities were not affected by trials with greater structural heterogeneity. Coefficients of variation for standing crop were 17 to $46 \%$ for burned trials and 19 to $88 \%$ in non-burned trials.

Visual obstruction was less effective at measuring standing crop when individual plots were used as observations (Fig. 2, Fig. 3). Separate models were required for estimating the standing crop of individual plots in burned and non-burned pastures $(\mathrm{P}<0.01)$. Coefficients of determination for models based on plots, 0.64 to 0.79 , were 16 to 26 percentage units lower than those for models based on trials. Models developed for sandhills sites had coeffi- cients of determination of only 0.31 to 0.41 (Volesky et al. 1999) but the range of standing crop sampled was smaller in the sandhills study. In contrast to our results, averaging data from 12 plots and constructing models based on pastures (or trials) did not improve the strength of the relationship between visual obstruction and standing crop (Volesky et al. 1999).

Regression models based on plots account for less variation because the true area measured by visual obstruction is unknown, 3-dimensional, and probably varies between points, but quadrat size is 2-dimensional and constant. Prediction models based on individual plots are dependent on the appropriateness of the quadrat design for any given point. Models developed at the trial level reduce this source of error by averaging both visual obstruction and standing crop over many points. At the trial level, visual obstruction is not associated with an arbitrary plot size. We recommend using models developed at the trial level because they are more relevant to measurement objectives and are also more precise.

Models developed from trial visual obstruction readings at 2.5 and $5.0-\mathrm{cm}$ increments were similar for burned $(\mathrm{P}=$ $0.98)$ and non-burned $(\mathrm{P}=0.94)$ pastures (Table 1). Increasing the precision of visual obstruction readings did not improve the precision of standing crop estimates. Either the method was not sensitive to small changes in visual obstruction or observers were unable to make accurate readings at $2.5-\mathrm{cm}$ increments. We believe

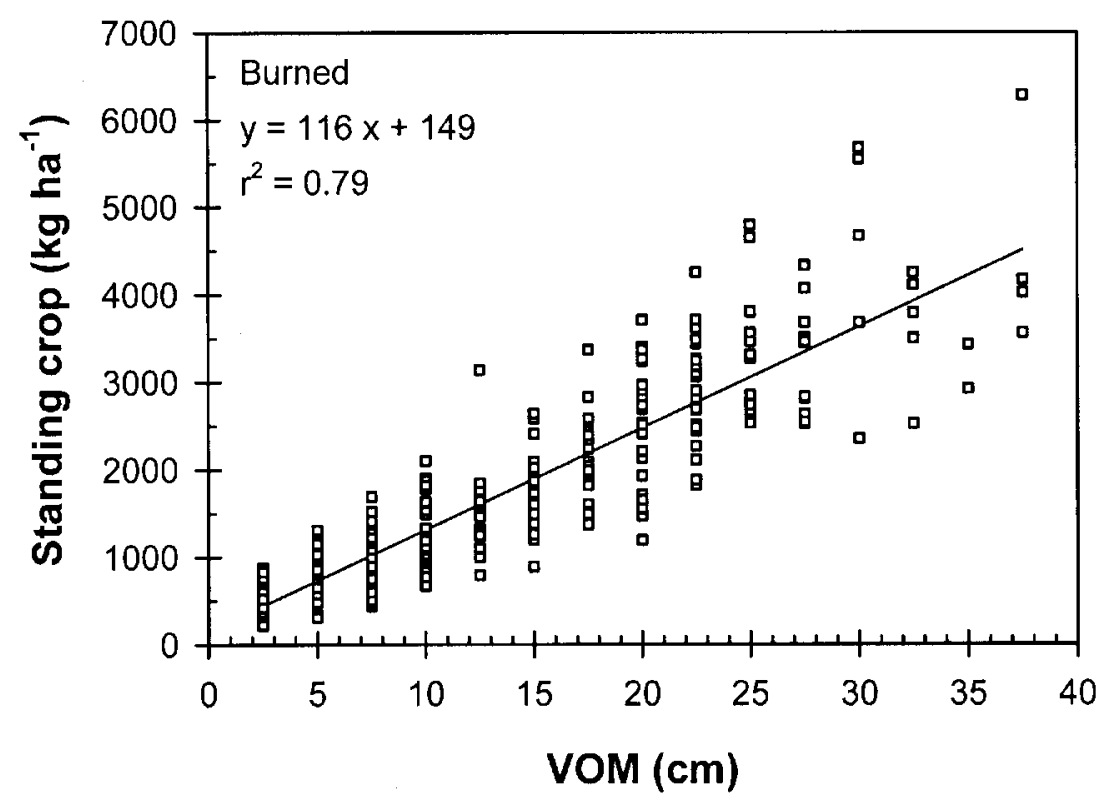

Fig. 2. Relationships between plot standing crop and visual obstruction measurements (VOM) in burned pastures $(n=350)$. 


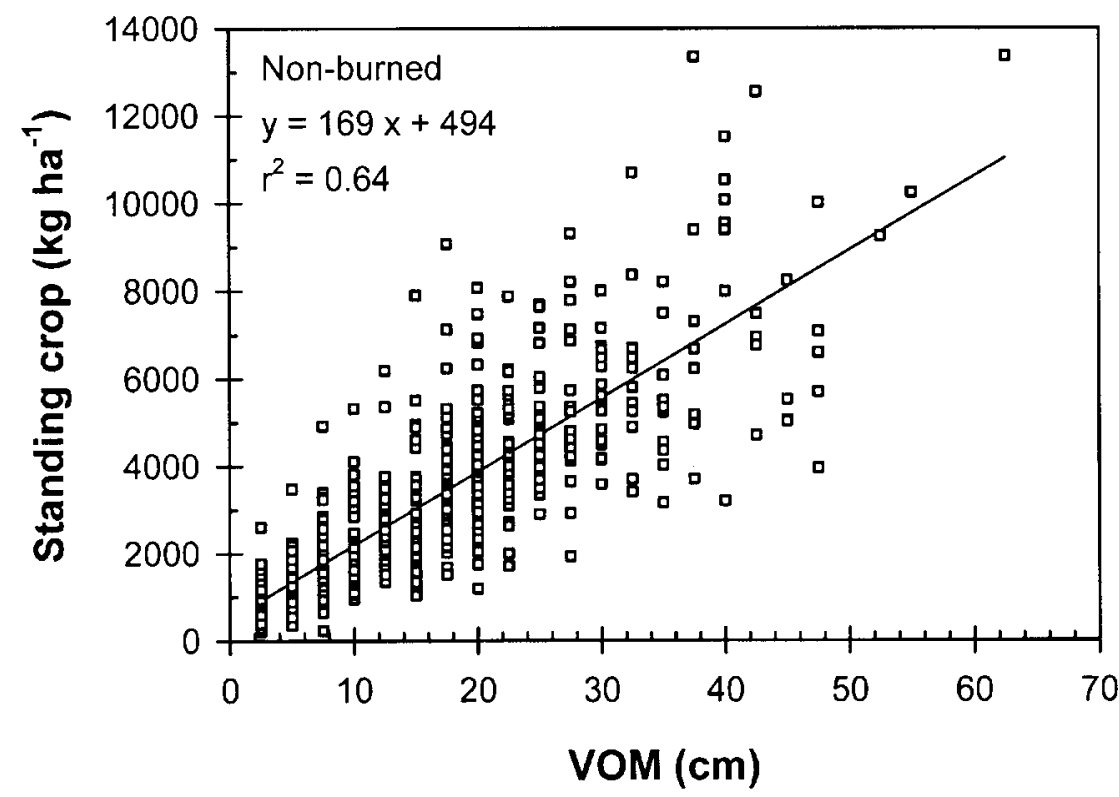

Fig. 3. Relationships between plot standing crop and visual obstruction measurements (VOM) in non-burned pastures $(n=619)$.

the method was not sensitive to small changes in visual obstruction increment. Harmoney et al. (1997) used a 4 x 16-mm telescope to take readings and explained $63 \%$ of the variation in standing crop with individual visual obstruction readings. We obtained similar values from non-burned sites using $2.5-\mathrm{cm}\left(\mathrm{r}^{2}=0.64\right)$ and $5.0-\mathrm{cm}$ $\left(\mathrm{r}^{2}=0.63\right)$ increments when individual readings were taken without visual aids and regressed on standing crop.

Visual obstruction measurements were correlated with standing crop estimates from all plot designs $(\mathrm{P}<0.01)$. The strongest correlation was with $20 \times 50 \mathrm{~cm}$ quadrats $(\mathrm{r}=0.78)$, followed by subplots adjacent to the measurement stick ( $\mathrm{r}=$ $0.75)$ and those nearest the observer $(r=$ $0.63)$. We believe plant stature and morphology are the primary factors controlling the volume measured by visual obstruction. As vegetative height increases, plants farther from the measurement pole contribute to visual obstruction and longer quadrats would be required. The appropriate quadrat width should depend on whether canopies of dominant plants are horizontally compressed or diffuse. Large, widely-spreading plants adjacent to narrow plots could affect visual obstruction readings because they would cause visual obstruction but could not be accounted for by clipping since they are not rooted in the plot. In this case, all vegetation above the plot should be clipped, whether or not it is rooted in the plot. As structural homogeneity increases, plot size and shape become less important.
Mean deviations of student readings were $1.8,1.3$, and $1.0 \mathrm{~cm}$ from those of the trainer after a verbal description of the visual obstruction method. Visual demonstrations reduced the deviations to $0.8,0.6$, and 0.3 $\mathrm{cm}$. The low variability of measurements among observers with only brief training indicates the visual obstruction method is an objective estimation technique.

To achieve equal precision between clipping and visual obstruction methods in burned pastures, an average of 44 plots must be clipped. The required number of clip plots varied with trial and ranged from 3 to 127 . For unburned pastures, the number of clip plots required for equal precision averaged 346 and ranged from 36 to 1645. About 6 visual obstruction measurements could be taken in the $2 \mathrm{~min}$. required to clip a $0.1-\mathrm{m}^{2}$ quadrat. On average, the time required to clip plots would require $88 \mathrm{~min}$. in burned pastures and 692 min. in unburned pastures while visual obstruction would require $6.6 \mathrm{~min}$. in both burned and unburned pastures. We assume that if plots were equally distributed over the sample area, total travel time between plots would be equal between methods. These comparisons do not include the time required to dry and weigh clip samples.

\section{Conclusion}

The visual obstruction method is an effective, non-destructive tool for estimating herbaceous standing crop in tallgrass prairie. Although separate VOM models were required for non-burned pastures and those that had been burned since the previous growing season, our models predicted standing crop year-round across multiple range sites, seral stages, and stocking rates. Because the method is reasonably accurate and much faster than clipping, the amount of data obtained per unit of time can be increased greatly. Additionally, fewer materials are required in the field, the need for drying and weighing vegetation is eliminated, and standing crop estimates can be calculated immediately by entering the mean visual obstruction into the appropriate regression model. Additional tests should be conducted to evaluate the applicability of the visual obstruction method and tallgrass prairie models to other rangeland regions.

\section{Literature Cited}

Catchpole, W.R. and C.J. Wheeler. 1992. Estimating plant biomass: a review of techniques. Australian J. Ecol. 17:121-131.

Gonzalez, M.A., M.A. Hussey, and B.E. Conrad. 1990. Plant height, disk, and capacitance meters used to estimate bermudagrass herbage mass. Agron. J. 82:861-864.

Harmoney, K.R., K.J. Moore, J.R. George, E.C. Brummer, and J.R. Russell. 1997. Determination of pasture biomass using four indirect methods. Agron. J. 89:665-672.

Michalk, D.L. and P.K. Herbert. 1977. Assessment of four techniques for estimating yield on dryland pastures. Agron. J. 69:864-868.

Myers, H.R. 1982. Climatological data of Stillwater, Oklahoma, 1893-1980. Oklahoma Agr. Exp. Sta. Res. Rep. P-821.

Neter, J., M.H. Kutner, C.J. Nachtscheim, and W. Wasserman. 1990. Applied linear regression analysis. Richard D. Irwin, Chicago, Ill.

Pieper, R.D., C.H. Herbel, D.D. Dwyer, and R.E. Banner. 1974. Management implications of herbage weight changes on native rangeland. J. Soil Water Conserv. 29:227-229.

Ratliff, R.D. and H.F. Heady. 1962. Seasonal changes in herbage weight in an annual grass community. J. Range Manage. 15:146-149.

Robel, R.J., J.N. Briggs, A.D. Dayton, and L.C. Hulbert. 1970. Relationships between visual obstruction measurements and weight of grassland vegetation. J. Range Manage. 23:295-297.

SAS Institute. 1985. SAS/STAT Guide for personal computers, Version 6 ed. Cary, N.C.

Steel, R.G.D., and J.H. Torrie. 1980. Principles and procedures of statistics. McGraw-Hill Book Co., New York.

Volesky, J.D., W.D. Schacht, and P.E. Reece. 1999. Leaf area, visual obstruction, and standing crop relationships on Sandhills rangeland. J. Range Manage. 52:494-499. 